\title{
WASTE MANAGEMENT FOR PRODUCTION OF STEEL ELECTRIC WELDING PIPES USING DATA MINING TECHNOLOGIES AND MES SYSTEMS
}

\author{
A. I. Shinkevich ${ }^{1}$, T. V. Malysheva ${ }^{1}$ \\ ${ }^{1}$ Kazan National Research University of Technology (Kazan, Russia) \\ E-mail: ashinkevich@mail.ru; tv_malysheva@mail.ru
}

\section{A UTHOR'S IN FO \\ A. I. Shinkevich, Dr. Econ., Prof., Head of the Dept. of Logistics and Management, T. V. Malysheva, Cand. Econ., Associate Prof., \\ Dept. of Logistics \\ and Management}

\section{Key words:}

steel pipes, industrial waste, scrap of ferrous metals, cleaning methods, emission of pollutants, resource intensity, MES system.

\author{
A B S T RACT
}

The article is devoted to the study of environmental problems in the production of steel pipes and the rational use of waste. The relevance of the study lies in the high resource intensity and waste of pipe metallurgy, the classification of steel production and their subsequent redistribution as the first category of environmental hazard and is assigned to the areas of application of the best available technologies. The aim of the article is to analyze the resource intensity and waste production of steel pipes, to study the existing waste management system and its rationality at Russian enterprises. As the main research methods, the IDEF0 modeling methodology was used to visualize the waste management system and to structurize the model for the production of welded pipes taking into account emissions of pollutants, as well as Data Mining technology in the form of a classification and regression tree for studying trends and local patterns in waste management. The tendency of increasing resource intensity at the enterprise of the pipe industry with relative financial instability is revealed. A visualization of the waste management system in the production of steel pipes is proposed, which makes it possible to distinguish the main functional blocks of the incoming and outgoing parts of the waste balance. A model of the processes of production of welded pipes is structured taking into account emissions of polluting substances into the atmosphere and cleaning methods according to the reference book on the best available technologies ITR 27-2017. Based on the constructed decision tree, knowledge was obtained on the trends in the treatment of steel pipe production waste. In order to reduce the level of rejection in the production of steel pipes and minimize the formation of scrap, a project has been proposed on the automation of technical quality control and the implementation of the MES system.

\section{Introduction and problem substantiation}

Technological processes of steel making and consequent steel processing are accompanied by forming of large amount of wastes containing different chemical components and other emissions being atmosphere pollutants. Ferrous metals production is classified as the first category of environmental hazard according to the RF legislation as an object having essential negative effect on the environment and is assigned to the arras of application of the best available technologies (BAT) [1-5].

More than 50 companies in Russia are the producers of steel pipes, hollow shapes and fittings. Based on 2019 data, these companies produced $2.3 \mathrm{mln}$. $t$ of wastes, or appr. 40,000 t of wastes for a company. It is known that not more than $27 \%$ of wastes is directed for reuse in self production and less than $1 \%$ of wastes is transferred to the third companies for recycling. At the same time substantial accumulated amount of wastes both inside these enterprises and in the storage areas for worked materials is observed [6]. According to the data of Rosprirodnadzor (Federal Supervisory Natural Resources Management Service), the total amount of wastes collected by the manufacturers of steel pipes, hollow shapes and fittings made about $50 \mathrm{mln}$. $t$ in the beginning of 2020. It is twenty times more than can be produced at the enterprises during a year. This statistics of wastes processing displays that resource intensity of production facilities achieves 0.9 rubles of raw materials for a product unit $[7,8]$.
The above-mentioned arguments testify about actuality of the wastes management problem in the field of pipe metallurgy. It is quite necessary to investigate the current situation with use of wastes, to reveal local regularities in creation of a "route" for wastes, to determine the problem areas in operation of ecological services.

\section{Research methods}

As the main research methods for examination of ecological problems connected with steel pipes manufacture and rational recycling of wastes, the IDEF0 modeling methodology was used to visualize the waste management system and to structurize the model for the production of welded pipes taking into account emissions of pollutants and cleaning methods.

The Data Mining technology in the form of a classification and regression tree (CART) was used as well for getting knowledge in wastes management. It allows to study statistical relationship between dependent variable and several independent predictors and to classify the examined objects.

\section{Discussion of results}

Production resource intensity in the Russian iron and Steel industry at present time is higher than in the economically developed countries. E.g. the metal utilization factor at the Russian metal processing enterprises makes in average $73 \%$, while in the USA in achieves $87 \%$ 


\begin{tabular}{|c|c|c|c|}
\hline & 2018 & 2019 & $\begin{array}{c}\text { Growth rate } \\
2019 / 2018, \%\end{array}$ \\
\hline \multicolumn{4}{|c|}{$\begin{array}{l}\text { Parameters of production resource intensity } \\
\text { (resources per product unit, rubles) }\end{array}$} \\
\hline \begin{tabular}{|l|} 
Resources for manufacture \\
and realization of products
\end{tabular} & 1.04 & 1.08 & 103.3 \\
\hline Material resources & 0.95 & 0.97 & 102.1 \\
\hline Raw materials & 0.90 & 0.92 & 101.6 \\
\hline Fuel, power, water & 0.01 & 0.02 & 114.3 \\
\hline \multicolumn{4}{|c|}{ Parameters of production efficiency (\%) } \\
\hline $\begin{array}{l}\text { Part of intermediate consumption in } \\
\text { production volume }\end{array}$ & 97.50 & 99.88 & 102.4 \\
\hline $\begin{array}{l}\text { Part of added value in production } \\
\text { volume }\end{array}$ & 2.50 & 0.12 & 4.7 \\
\hline
\end{tabular}

$[9,10]$. Thereby, essential metal part in Russia is transformed in chips. Resource intensity at Almetyevsk tube plant (a member of United metallurgical company OMK) increases by $2.1 \%$ during recent two years and made 0.97 rubles of material resources per product unit. It means that manufacture of products with 1 ruble cost will require 0.97 rubles of material resources, including 0.92 rubles of raw materials and 0.02 rubles of fuel and power resources [11, 12].

High level of resource consumption does not provide financial stability and resources for development of production system at an enterprise. It is shown that the loss of the tube plant increased during last two years, while the part of added value in 2019 production volume is close to the zero mark $(0.12 \%)$. Significant amounts of residual stocks and unfinished products tale place at the enterprise.

The system of wastes processing at the works for manufacture of steel pipes, hollow shapes and fittings includes the following functional blocks (Fig. 1).

As a result of operation of wastes management system, balance carried forward $(Y)$ is forming; it reaches $95 \mathrm{mln}$. $t$ at Russian pipe plants.

Accumulation of production wastes (balance carried forward) $Y$ can be presented as a mathematical expression having receipt and expense sections:

$$
Y=\Sigma\left(X_{1}, X_{2}, X_{3}\right)-\Sigma\left(X_{4}, X_{5}, X_{6}, X_{7}\right) \text {. }
$$

When $Y=0$, the balance equation for the wastes processing system will looks like:

$$
\Sigma\left(X_{1}, X_{2}, X_{3}\right)-\Sigma\left(X_{4}, X_{5}, X_{6}, X_{7}\right) \text {. }
$$

One tube plant was characterized in average by $\Sigma\left(X_{1}, X_{2}, X_{3}\right)=1.66 \mathrm{mln} \mathrm{t}$ of wastes in the beginning of 2019 with expense section $\Sigma\left(X_{4}, X_{5}, X_{6}, X_{7}\right)=0.043 \mathrm{mln}$. t. Thereby the amount of the expense section was less than the receipt section by 38 times, while the residue $Y$ in the end of the year makes $1.62 \mathrm{mln}$. $\mathrm{t}$ of wastes. Decrease of the amount of production wastes at the works constitutes only 40,000 t. Such situation testifies about necessity of re-engineering of the wastes processing system which is not sufficiently rational at present time.

Let us consider the kinds of wastes in production of spiral welded pipes that are forming in the main technological processes such as welding, heat treatment and cleaning. The model of this technological process containing five principal modules (A1-A5) was structurized by the authors (Fig. 2).

The pollutants from A1, A2 and A4 modules present emission of welding aerosol including solid and gaseous toxic substances containing different metals and their compounds, as well as emission of inorganic dust with silicon dioxide content up to $70 \%$. A3 module provides emission of inorganic dust in the atmosphere and A5 module - residues of flux and scale.

The best available technology for cleaning of emissions of pollutants during pipe welding (A1), regeneration of welding flux (A3) and plasma pipe cutting (A4) is wet dust collection of dust and gas emissions [13]. Parameters of air cleaning from its dust component can reach 80$90 \%$ in the modern wet dust collectors. Possibility of using such collectors as heat exchangers and absorbers, providing probably to save resources and equipment capital intensity to a certain extent, can be considered as their advantage. There is no doubt that wet dust collector is the optimal one in the field of physical and chemical cleaning technology. However, efficiency of such collectors depends essentially on its construction, on the form of contact between solid and liquid technological phases and on parameters of collecting particles [14, 15]. Information and technical directory on BAT (ITR 27-2017) does not describe completely the features of the existing collectors in relation of production technologies and dimension ranges of pipe products, what makes it difficult to organize environmental friendly technologies.

Local extract ventilation is used in Russian metallurgy for blowing of pipes in the atmosphere (A2); it prevents distribution of harmful substances along a production site. Exhausters are usually used for this purpose; they

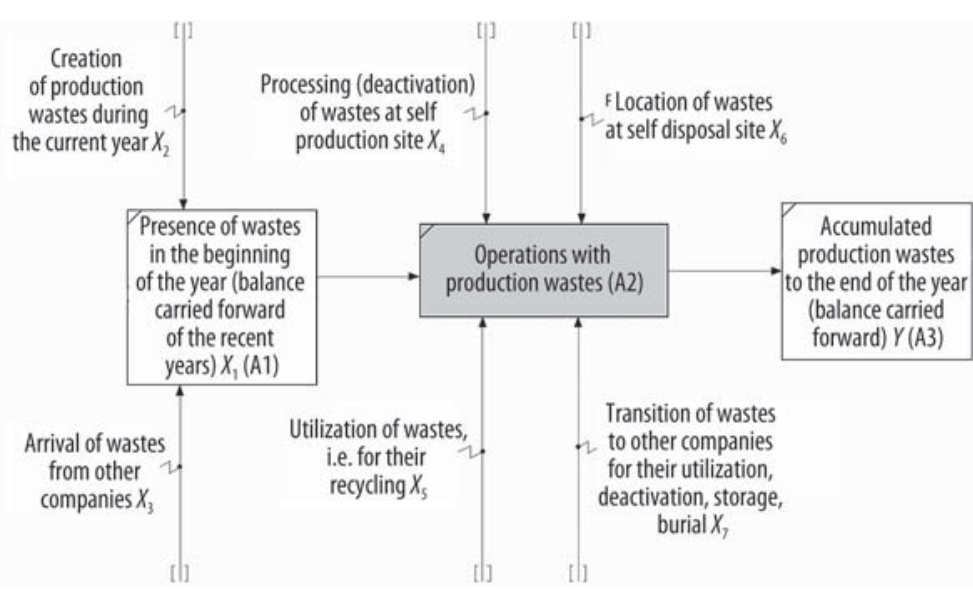

Fig. 1. Visualization of the wasted processing system in production of steel pipes, hollow shapes and fittings 


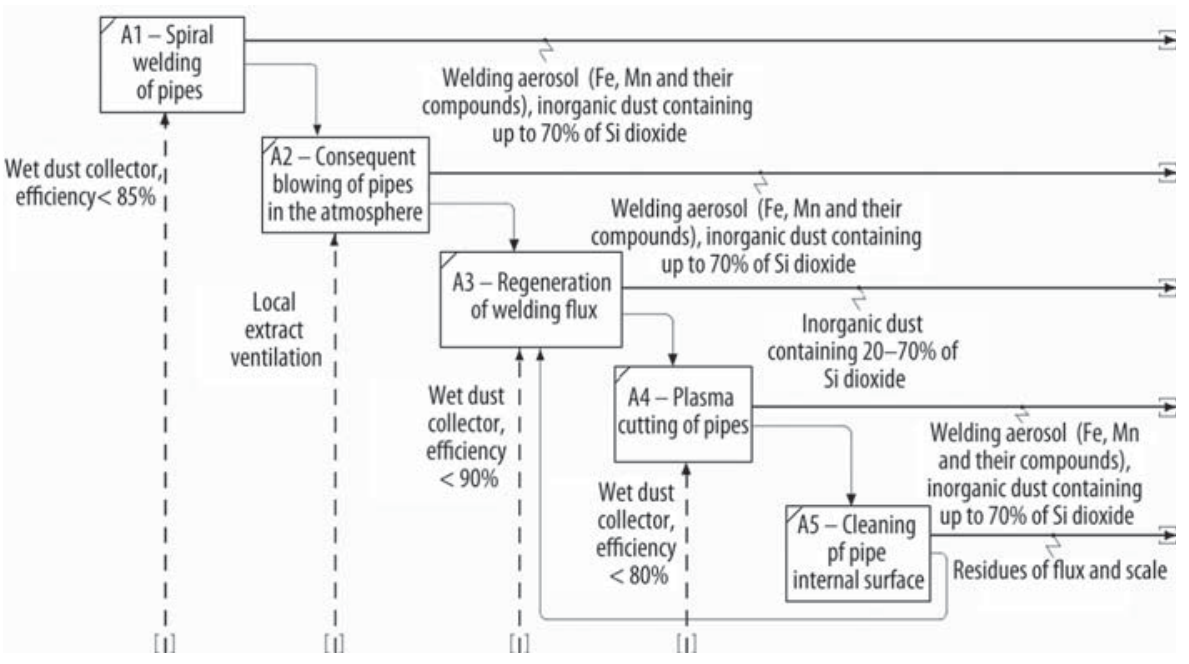

Fig. 2. The model of technological process for welded pipes, taking into account emissions of pollutants in the atmosphere and cleaning methods

are integrated in welding equipment or in turning-lifting and mobile air collectors with different construction [16]. Efficiency of ventilation system depends mainly on correspondence between ventilator capacity, its construction and welding type.

According to the 2020 Federal classification catalogue of wastes (FCCW-2020), the wastes of production of steel tubes, hollow sections and fittings correspond to 352 group of wastes, including 16 sorts of wastes related to different technological stages of production [17]. Additionally, the list of wastes includes also scarp and wastes of ferrous metals in the form of products and pieces (4 60 group of wastes). Based on the data of Rosprirodnadzor, there were 9 kinds of wastes at Russian steel pipe works in 2018; they were presented by products, pieces and wastes of the technological process (table 2). Those include three kinds of wastes (metal, dewatered residue of neutralization of hydrochloric acid water and dust from a gas cleaning unit during pipe sputtering) that have a balance carried forward. Other substances are used or transferred to the third companies.
Use of Data Mining technologies in the area of organizing solutions aimed on strengthening of ecological features of production process allows to create expert-diagnostic systems for quality control management of finished products and evaluation of production effect on the environmental system. Let us use the method of "Decision Tree" for getting the new knowledge, revealing the hidden regularities and relationships in wastes management for steel pipe production.

To examine the "route" of wastes and features of their usage, let us accept the level of wastes utilization in the company $(D w)$ as the independent variable $V d e p$. Thereby the following variables will be considered as independent predictors:

Pred 1 - part of wastes recycling $(R w)$;

Pred 2 - part of wastes, located at the self disposal sites $(P w)$

Pred3 - part of wastes, transferred to other companies (Tw).

To realize the method of Decision Trees, let us use Statistica software complex. The relationship between the dependent variable and independent predictors can be presented as a tree-shape structure obtained with help of hierarchic data segmentation (Fig. 3).

The Decision Tree has 3 non-terminal and 4 terminal knots (non terminal knots have subsidiary ones). Each new branch of the tree has $I D$ knot identifier, $N$ knot size, $M u$ average value and Varknot dispersion. Each iteration level in the knot of decision taking is supplied by conditions of forming of a new tree branch relating to the variable value that is most informative. After third iteration on the tree diagram 4 knots (ID $=3,5,6,7$ ) are formed; based on

\begin{tabular}{|c|c|c|c|c|}
\hline \multirow{2}{*}{ Kind of wastes in steel pipes production } & \multirow{2}{*}{$\begin{array}{c}\text { Presence of wastes } \\
\text { in the beginning } \\
\text { of the year }\end{array}$} & \multicolumn{2}{|c|}{ Circulation of wastes } & \multirow{2}{*}{$\begin{array}{l}\text { Residue of wastes } \\
\text { in the end of the year }\end{array}$} \\
\hline & & Receipt section & Expense section & \\
\hline Steel scrap and wastes in pipe production & 905708.8 & 71180404.9 & 71342077.6 & 744036.1 \\
\hline Flux wastes in welding of steel pipes & 0.0 & 878.6 & 878.6 & 0.0 \\
\hline Wastes of wet gas cleaning unit in steel pipe production & 0.0 & 116.5 & 116.5 & 0.0 \\
\hline Dust of gas cleaning unit in steel pipe production & 19.2 & 150.2 & 112.9 & 56.5 \\
\hline Dust of gas cleaning unit in scarfing of pipe ends & 0.0 & 191.9 & 191.9 & 0.0 \\
\hline Dust of gas cleaning unit in galvanizing of steel pipes & 0.0 & 15.5 & 15.5 & 0.0 \\
\hline Dewatered residue of neutralization of hydrochloric acid water & 51736.3 & 24266.4 & 24174.9 & 51827.8 \\
\hline $\begin{array}{l}\text { Solution of calcium chloride in neutralization of hydrochloric } \\
\text { acid water }\end{array}$ & 0.0 & 133.0 & 133.0 & 0.0 \\
\hline $\begin{array}{l}\text { Wastes of pipe cleaning and cleaning of technological } \\
\text { equipment }\end{array}$ & 0.0 & 234.8 & 234.8 & 0.0 \\
\hline
\end{tabular}


the authors' opinion, they can be accepted as classes or groups of examined wastes meaning the features of their processing (table 3).

The first group (ID = 3) includes two kinds of wastes with high specific weight of return of resources in production cycle for their secondary processing (steel scrap and wastes in pipe production, calcium chloride solution in neutralization of hydrochloric acid water). Recycling of steel scrap and wastes in pipe production $(R w)$ makes $54 \%$. The second group $(\mathrm{ID}=5)$ is formed for the part of wastes that were located at the self disposal sites for their storage and burial. The value $P w$ vv $>100 \%$ testifies about purchasing the resources and their storage at the self site (dust from a gas cleaning unit during pipe sputtering). The third group (ID =6) is the most numerous; it is characterized by the part of wastes located at the self disposal sites $(P w<71,6 \%)$ and includes five kinds of wastes (residue of neutralization of hydrochloric acid water, flux wastes in pipe welding, pipe cleaning wastes, dust from a gas cleaning unit in pipe galvanizing). This group also includes wastes that are not located at the self site of the works, but they are transferred to other companies for storage or utilization. The fourth group (ID =7) has intermediate values of the part of wastes located at the self storage sites: $125,7 \%>P w \mathrm{~K}_{4}>71,6 \%$ (wastes of wet gas cleaning).

Scrap and wastes containing non-contaminated ferrous metals as products and pieces are accumulated at the works in substantial amounts. This kind of wastes is classified as the $5^{\text {th }}$ class of hazard and is practically harmless $\wedge$ the level of danger for the environment is close to zero. However, large amount of residues of processed steel testifies about the problems in resources management. It seems that high volume of scrap forming in steel pipe production can be considered as presence of up to $10 \%$ of rejects. Part of rejects id inevitable - it is presented by products manufactured with violation of preset parameters owing to variations in the equipment fitting. The other part is described as violation of technological parameters and product quality due to the human factor. Consequently, efficient organization and management on production lines and quality control of finished products allow to minimize the part of rejected products and, respectively, to decrease the amount of scrap forming.
It is expedient to use in this direction information MES systems (Manufacturing Execution Systems), taking into account special features of technological business processes in metallurgy. The MES system available in Russia is "Galaktika AMM" software, where AMM means Advanced Manufacturing Management. This information system has wide functionality in management of equipment and technological processes, what allows to provide automation of control functions for product quality in the principal pints of production technological cycle. Timely determination of products that don't meet the requirements makes it possible to realize the adjusting measures and to decrease thereby the level of rejection and forming of metal wastes.

Approximate cost of the software with accompanying of all works makes $1.55 \mathrm{mln}$. rubles. Operation of the MES system is possible on the mobile platform 1C: Enterprise 8.3. The expected economical effect after use of the software complex in management of technological processes in general and in the field of product quality control in particular is presented in the Table 4.

Through metal barcoding, accounting of wastes and losses at the enterprise allow to decrease material expenses by $8.8 \%$ and production expenses in general - by $12.3 \%$. Automation of the technical control system, collection of analyses and quality control services provides lowering of

\begin{tabular}{|l|c|c|c|c|}
\hline \multirow{2}{*}{ Table 3. Parameters of wastes classification meaning the features of their processing and based on Classification and Regression Tree } \\
\hline \multirow{2}{*}{ Parameters of Decision Tree } & \multicolumn{4}{c|}{ Classification of enterprises } \\
\cline { 2 - 5 } & Group 1 $\left(\mathrm{K}_{1}\right)$ & Group 2 $\left(\mathrm{K}_{2}\right)$ & Group 3 $\left(\mathrm{K}_{3}\right)$ & Group 4 $\left(\mathrm{K}_{4}\right)$ \\
\hline Condition of an enterprise classifying to a group & $\mathrm{Rw} \mathrm{K} \mathrm{K}_{1}>34.7 \%$ & $\mathrm{Pw} \mathrm{K}_{2}>125.7 \%$ & $\mathrm{Pw} \mathrm{K}_{3}<71.6 \%$ & $125.7 \%>\mathrm{Pw} \mathrm{K}_{4}>71.6 \%$ \\
\hline Knot size N & 2 & 1 & 5 & 1 \\
\hline Average knot value Mu & 314.6 & 303.1 & 92.9 & 0.0 \\
\hline Knot dispersion Var & 95.6 & 0.0 & 202.4 & 0.0 \\
\hline
\end{tabular}




\begin{tabular}{|l|c|c|c|}
\hline \multicolumn{4}{|l|}{$\begin{array}{l}\text { Table 4. The expected economical effect after use of MES system software complex in management of production processes of steel } \\
\text { pipes aimed on minimization of scrap formation (on the example of "Almetyevsk tube plant" JSC) }\end{array}$} \\
\hline & $\begin{array}{c}\text { Before putting MES } \\
\text { system into practice }\end{array}$ & $\begin{array}{c}\text { After putting MES system } \\
\text { into practice }\end{array}$ & $\begin{array}{c}\text { Expected economical } \\
\text { effect }\end{array}$ \\
\hline $\begin{array}{l}\text { Expenses for production and selling of products, thousand } \\
\text { rubles }\end{array}$ & 6741954.2 & 5912693.6 & -829260.3 \\
\hline Material expenses, thousand rubles & 6106564.1 & 5575292.9 & -531271.1 \\
\hline Operation and management expenses, thousand rubles & 149317.0 & 125724.9 & -23592.09 \\
\hline Profit (loss) of production, thousand rubles & -478712.0 & -436585.4 & -42126.6 \\
\hline Level of rejection, \% & 7.5 & 2.7 & -4.8 \\
\hline Amount of scarp and wastes, $t$ & 8115.2 & 5357.9 & -2757.3 \\
\hline
\end{tabular}

rejection level down to $4.8 \%$. Respectively, possibility of the amount of steel scrap and wastes formed during a year in pipe production makes more than $30 \%$.

Suggestion for putting MES systems into practice was supported by the Ministry of Economics of Tatarstan Republic within the framework of Tatarstan technological initiative "Strategy 2030" and corresponds with OMK ideology in the area of creation of digital production [18].

\section{Conclusions}

Examination of the environmental problems of steel pipes production and rational usage of the wastes allowed to obtain the following scientific and practical results.

1. Resource intensity of steel pipes production on the example of Almetyevsk tube plant reaches 0.97 rubles of material resources on product unit with negative financial result and the part $0.12 \%$ of the added value in production volume. Residues of finished and unfinished products are presented at the enterprise.

2. Visualization of the wastes processing system in production of steel pipes, hollow shapes and fittings allows to extract the main functional blocks of receipt and expense sections of wastes balance. It is determined on the example of the tube making enterprises that the value of expense section is larger than the value of receipt section by 38 times, while residue of wastes in the end of the year reaches $1.6 \mathrm{mln}$. t.

3. The technological model of welded pipe production is structurized taking into account emissions of pollutants in the atmosphere and cleaning methods. Necessity of optimization of the reference book on the best available technologies ITR 27-2017 is substantiated; it does not allow the users to receive completely information about variety and features of cleaning methods in relation to the methods of pipe production and kinds of pipe products.

4. Emission of pollutants and wasted of ferrous metals manufacture in production of steel pipes, hollow shapes and fittings is analyzed. Based on the Decision Tree, the knowledge on the tendencies of wastes processing in steel pipe production is received. The results allow to make conclusion about different approach to wastes management, i.e. in digital form. Economical efficiency from re-engineering of the wastes management system in steel pipes production can be received as a result of increase of the part of wastes returned to the technological cycle up to $70-90 \%$ depending on the kind of resource. Use of outsourcing technologies for wastes, i.e. complete $(100 \%)$ or partial $(50-80 \%)$ transfer of resource to other specialized companies, can provide economical efficiency in the form of reduction of self wastes disposal sites and their service. Calculation of the value of economical efficiency will be possible during development of concrete project on optimization of wastes management and resource saving.

5. In order to decrease the level of rejects in steel pipe production and minimization of scrap forming, the project on automation of technical quality control and putting the MES system into practice is suggested. The economical efficiency of the software product use in management of production processes at Almetyevsk tube plant can reach $12 \%$ of saving expenses on products and decrease of production losses by $8 \%$. At the same time lowering of the level of product rejects by $2.7 \%$ allows to decrease scrap forming at the enterprise by up to $30 \%$.

The research was carried out within the framework of the grant of the President of the Russian Federation for state support of leading scientific schools of the Russian Federation, project number NSh-2600.2020.6.

\section{REFERENCES}

1. Sethurajan M., Hullebusch E., Fontana D. et al. Recent advances on hydrometallurgical recovery of critical and precious elements from end of life electronic wastes-a review. Critical reviews in environmental science and technology. 2019. Vol. 49(3). pp. 212-275.

2. Peters K., Malfa E., Colla V. The European steel technology platform's strategic research agenda: a further step for the steel as backbone of EU resource and energy intense industry sustainability. Metallurgia Italiana. 2019. Vol. 5. pp. 5-17.

3. Balaram V. Rare earth elements: A review of applications, occurrence, exploration, analysis, recycling, and environmental impact. Geoscience Frontiers. 2019. Vol. 10 (4). pp. 1285-1303. 
4. Butorina I. V., Butorina M. V. Issues of implementing the best available technologies in the steel industry of the Russian Federation. Chernye metally. 2019. No. 1. Pp. 43-48.

5. On environmental protection [Electronic resource]: Federal Law as amended on July 31, 2020 № 7-FZ. Reference and legal system "Consultant Plus".

6. Kolotyrin K. P., Bogatyrev S. A., Savon D. Yu., Aleksakhin A. V. Use of resource-saving technologies in fabrication and restoration of steel bushing-type components via hot plastic deformation. CIS Iron and Steel Review. 2019. Vol. 18. pp. 38-41.

7. Dyrdonova A. N., Shinkevich A. I., Galimulina F. F., Malysheva T. V., Zaraychenko I. A., Petrov V. I., Shinkevich M. V. Issues of industrial production environmental safety in modern economy. Ekoloji. 2018. Vol. 27, 106. pp. 193-201.

8. Shinkevich A. I., Malysheva T. V., Ryabinina E. N., Morozova N. V., Sokolova G. N., Vasileva I. A., Ishmuradova I. I. Formation of network model of value added chain based on integration of competitive enterprises in innovation-oriented cross-sectorial clusters. International Journal of Environmental and Science Education. 2016. Vol. 11, 17. pp. 10347-10364.

9. Hue Nguyen Th., Thuy N., Long Pham H., et al. Emission of Unintentionally Produced Persistent Organic Pollutants from Some Industrial Processes in Northern Vietnam. Bulletin of Environmental Contamination and Toxicology. 2019. Vol. 102(2). pp. 287-296.

10. Reuter M., Schaik A., Gutzmer J. et al. Challenges of the Circular Economy: A Material, Metallurgical, and Product Design Perspective. Annual Review of Materials Research. 2019. Vol. 49. pp. 253-274.
11. "OMK summarized the operation in 2018" [Electronic resource]: URL: https://omk.ru/atz/smi/25165/?Back_url_ list $=/ \mathrm{atz} /$.

12. Kostyukhin Yu. Yu., Savon D. Yu. Improving steel market performance indicators in the face of increased competition. Chernye metally. 2020. No. 4. pp. 68-72.

13. Information and technical reference book on the best available technologies ITR 27-217 "Manufacture of ferrous metals products for further processing" NTD Bureau, 2017. 394 p.

14. Claudiney M., Adhimar O., Daniela S. et al. A New Method to Recycle Stainless-Steel Duplex UNS S31803 Chips. Metals. 2018. Vol. 8 (7). p. 546.

15. Rajskaya M. V., Sagdeeva A. A., Panteleeva Yu. V., Malysheva T. V., Ershova I. G. Differentiated approach problems to innovative development management in Russian regions. Humanities and Social Sciences Reviews. 2019. Vol. 7, 4. pp. 1262-1268.

16. Malysheva T. V., Shinkevich A. I., Ostanina S. S., Vodolazhskaya E. L., Moiseyev V. O. Perspective directions of improving energy efficiency on the meso and micro levels of the economy. Journal of Advanced Research in Law and Economics. 2016. Vol. 7, 1. pp. 75.

17. Wastes from the production of steel pipes, hollow profiles and fittings. [Electronic resource]: FKKO URL: http://kod-fkko. ru/kod-35200000000-othody-proizvodstva-stal/.

18. «OMK told CNews how digital technologies help the company in the conditions of staff shortages». CNews, 04/21/2020. [Electronic resource]. URL: https://cnews.ru/articles/202004-16_v_omk_rasskazali_cnewskak_tsifrovye.

\section{A. Bocharov, V. A. Ignatkina}

\section{Technology of mineral processing}

\section{in 2 volumes*}

- Mineral raw materials base

- TeChNology of raRe metals processing

- TECHNOLOGY OF NON-FERROUS METALS PROCESSING

- TeChNology of RARE MEtals PRocessing

- Processing of gold-bearing ores and alluvial deposits

- Processing of ferrous ores

- Processing of carbon group ores

- Processing of mining-Chemical and non-metallic RaW materials

- Production organization and MANAGEMENT on PROCESSING PLANTS

Реклама

Advertisement

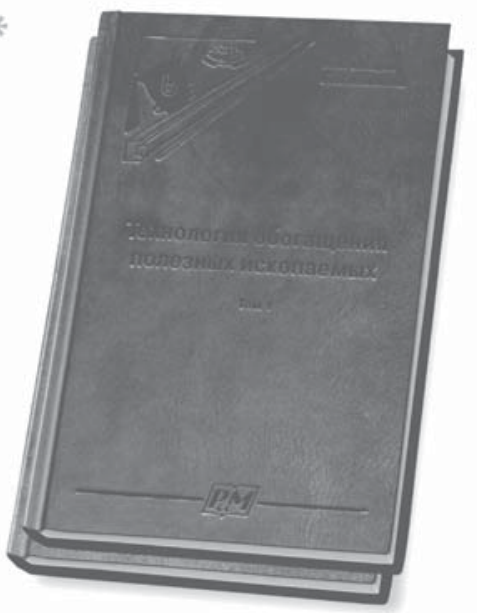

If you want order this book, you should send your request: P. O. Box 71, B-49, Moscow, 119049, Russia

Phone +7(495) 955-01-75

E-mail: books@rudmet.com Internet: http://www.rudmet.com

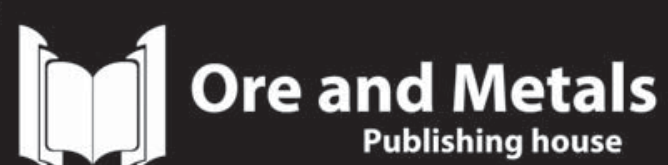

